\title{
Penggunaan Social media influencer Sebagai Usaha Membangun Budaya Masyarakat Digital Tentang Konsep Tubuh Ideal dan Kepercayaan Diri
}

\author{
Azizun Kurnia Illahi, Dewanto Putra Fajar, Muhammad Irawan Saputra \\ Program Studi Ilmu Komunikasi, Jurusan Ilmu Komunikasi, Fakultas Ilmu Sosial dan Ilmu Politik, \\ Universitas Brawijaya. Ketawanggede, Kec. Lowokwaru, Kota Malang, Jawa Timur 65145 \\ azizun.nia@ub.ac.id,dewanto.pf@ub.ac.id,m.irawans@ub.ac.id
}

Masuk tanggal : 19-01-2020, revisi tanggal : 01-07-2020, diterima untuk diterbitkan tanggal :02-07-2020

\begin{abstract}
Social media influencers have a wide influence on users of social media, by entering new messages or popularizing certain issues. This makes the audience more aware of a particular issue in society, including on the topic of self-confidence or about the ideal body shape for women. The discussion about self-confidence or ideal body shape becomes a serious and important discourse for modern society. So that the activity of spreading information about it becomes important for the audience, because of that the role of influencer social media is important to know, especially on messages presented in social media. This research uses qualitative methods, with qualitative content analysis methodology. The purpose of this study is to determine the role of influencers in social media in providing messages relating to the ideal body concept to build self-confidence. The use of content analysis makes the writer have a better chance to provide deeper observation and analysis of the textual aspects of messages in social media, especially messages related to self-confidence and ideal body shape. This article finally gets important empirical findings that social media influencers have a big role to play in important information for social media users, which traditional media cannot tend to provide. Content created by social media influencers as communicators provides a new understanding of ideal body concepts that are not only related to physical appearance and beauty but also relate to the way individuals maintain body health.
\end{abstract}

Keywords: communicators, ideal body concepts, social media, social media influencers

\begin{abstract}
Abstrak
Social media influencer memberikan pengaruh luas kepada pengguna media sosial, dengan cara memasukkan sejumlah pesan baru atau mempopulerkan isu tertentu. Hal itu menjadikan audiens menjadi lebih sadar tentang suatu isu tertentu dalam masyarakat, termasuk juga pada topik tentang kepercayaan diri atau tentang bentuk tubuh ideal bagi perempuan. Adanya bahasan mengenai kepercayaan diri atau pun bentuk tubuh ideal menjadi wacana serius dan penting bagi masyarakat modern. Sehingga aktivitas penyebaran informasi tentang hal itu menjadi penting bagi audiens, karena itu peran sosial media influencer menjadi penting untuk diketahui, khususnya pada pesan-pesan yang disajikan di dalam media sosial. Penelitian ini menggunakan metode kualitatif, dengan metodologi analisis isi kualitatif. Tujuan penelitian ini adalah mengetahui peran social media influencer dalam memberikan pesan berkaitan dengan konsep tubuh ideal untuk membangun kepercayaan diri. Penggunaan analisis isi menjadikan penulis memiliki kesempatan lebih baik untuk memberikan pengamatan dan analisis lebih dalam terhadap
\end{abstract}


aspek teksktual pesan dalam media sosial, khususnya pesan-pesan terkait dengan kepercayaan diri dan bentuk tubuh ideal. Artikel ini pada akhirnya mendapatkan temuan empiris penting bahwa social media influencer memiliki peranan besar untuk memasukkan sejumlah informasi penting bagi pengguna media sosial, yang cenderung tidak bisa diberikan oleh media-media tradisional. Konten-konten yang dibuat oleh social media influencer sebagai komunikator memberikan pemahaman baru tentang konsep tubuh ideal yang tidak hanya berkaitan dengan penampilan fisik dan kecantikan tetapi juga berhubungan dengan cara individu menjaga kesehatan tubuh.

Kata Kunci: komunikator, konsep tubuh ideal, media sosial, social media influencer

\section{Pendahuluan}

Awal tahun 1970an, Wilbur Schramm memberikan pernyataan dalam karya tulisnya yang menyatakan bahwa Teori Peluru (bullet theory) dianggap tidak ada, setelah ia menemukan fakta bahwa audien massa ternyata merupakan audien yang aktif. Kenyataan demikian menunjukkan bahwa audien memiliki kesempatan untuk memilih medianya sesuai dengan kebutuhannya, serta bukan lagi menjadi sasaran pasif bagi media. Pandangan tersebut didukung oleh rekan sejawatnya Paul F. Lazarfeld bahwa audien secara aktif tidak lagi bisa secara mudah dikendalikan oleh informasi dari media. Dengan kata lain, peluru informasi media tersebut tidak menembus dan adakalanya pula efek yang timbul berlainan dengan tujuan si penembak (Wahyudin, et al, 2010). Pandangan revolusioner Schramm mengubah arah kajian komunikasi, yang pada awalnya bertumpu pada media, kini beralih ke ranah audien. Situasi demikian memunculkan gerakan besar bernama CIP (Cultural Indicators Project), yang secara sistematis berusaha menemukan teori-teori baru dalam ilmu komunikasi, yang tidak hanya bertumpu pada media, tapi lebih berkonsentrasi pada peran audien terhadap media (L. H. Morgan, 2008). CIP menghasilkan sejumlah besar teori-teori komunikasi baru, termasuk di antaranya ialah, Teori Kultivasi (Cultivation Theory), dan Teori Penggunaan dan Kepuasan (Uses and Gratification Theory), atau lebih dikenal sebagai U\&G. Teori U\&G pertama kali dikembangkan oleh Jay G. Blumler, Michael Gurevitch, dan Elihu Katz, berasumsi bahwa audien secara bebas bisa memilih menggunakan medianya, sebagai sarana untuk memenuhi kebutuhannya, sekaligus mendapatkan kepuasan (Gilovich \& Griffin, 2012). Teori U\&G merevolusi pandangan klasik yang menyatakan bahwa audien dipengaruhi sepenuhnya oleh media, menjadi pandangan baru, yang menyatakan bahwa media tidak lagi mampu menguasai audien sepenuhnya, karena audien memiliki kebebasan penuh untuk menggunakan medianya. Dengan demikian Teori U\&G ini mengasumsikan bahwa pengguna mempunyai pilihan alternatif untuk memuaskan kebutuhannya (Nurudin, 2013). Menariknya, perkembangan internet dewasa ini mendorong munculnya sejumlah perubahan besar dalam proses komunikasi manusia, sekaligus ikut mengubah asumsi dasar Teori U\&G menjadi teori yang leih mutakhir, yaitu Teori U\&G 2.0. Teori tersebut berasumsi bahwa audien tetap berusaha mencari kepuasan ketika menggunakan internet atau media sosial, sehingga semua tindakan mereka di ranah internet dan atau media sosial bertujuan memenuhi kebutuhan mereka, demi mendapatkan kepuasan, sama seperti ketika mereka menggunakan media-media 
Azizun Kurnia Illahi, Dewanto Putra Fajar, Muhammad Irawan Saputra: Penggunaan Social media influencer Sebagai Usaha Membangun Budaya Masyarakat Digital Tentang Konsep Tubuh Ideal dan Kepercayaan Diri

tradisional (West \& Turner, 2019). Asumsi demikian menunjukkan bahwa audien menggunakan motivasi tertentu ketika mereka menggunakan internet atau media sosial, yaitu motivasi memenuhi kebutuhan dan mendapatkan kepuasan, hampir sama dengan ketika mereka menggunakan media-media tradisional. Teori U\&G 2.0 dikembangkan dari hasil sejumlah penelitian besar yang dilakukan oleh sejumlah ilmuwan, termasuk (M. Morgan et al., 1999) yang secara aktif melakukan kritik terhadap Teori U\&G agar lebih bisa menyesuaikan dengan perubahan konsumsi media oleh audien-yang notabene lebih sering menggunakan media baru (West \& Turner, 2019). Perubahan konsumsi media oleh audien dewasa ini mendorong sejumlah perubahan besar terhadap arus informasi dari komunikator-media, menuju komunikan-audien.

Dewasa ini konsumsi media oleh audien, tidak hanya terbatas pada penggunaan media massa tradisional semata, tapi juga pada penggunaan media baru-internet dan media sosial, yang secara potensial lebih personal dan lebih mudah diakses oleh audien - secara personal. Keadaan demikian menunjukkan bahwa internet dan media sosial menjadi bagian dari kehidupan masyarakat modern saat ini. Menariknya, kondisi demikian mengubah cara masyarakat berkomunikasi, sehingga mayoritas audien saat ini menjadikan internet sebagai sarana untuk memenuhi kebutuhan informasi, khususnya yang tidak bisa didapatkan dari mediamedia tradisional. Hal itu memunculkan suatu kelompok baru, yang dikenal sebagai social media influencer, yang secara khusus menyediakan informasi-informasi spesifik kepada masyarakat modern, sesuatu yang tidak didapatkan dari media tradisional. Turkle (Saleh \& Pitriani, 2018) dalam sebuah jurnal yang berjudul Pengaruh Media Sosial Instagram dan WhatsApp Terhadap Pembentukan Budaya "Alone Together" menjelaskan bahwa "Ada beberapa orang atau sekelompok orang yang sedang berkumpul, tetapi mereka sibuk dengan melihat gawai (gadget) masing-masing. Itulah yang dinamakan dengan Alone Together. Munculnya Alone Together membuat seseorang acuh hampa dengan aktivitas sekitarnya. Sherry Turkle dalam bukunya Alone Together mengatakan perilaku yang sudah jadi tipikal bisa saja menunjukkan masalah yang dulu kita anggap sebagai penyakit. Turkle menjelaskan bahwa orang menjadi terisolasi dari realitas karena situs jejaring social dan teknologi mendominasi kita dan membuat kita "kurang manusiawi". Dalam ilusi bahwa kita sedang berkomunikasi lebih baik, teknologi sebenarnya menjauhkan kita dari interaksi nyata manusia lewat cyber reality yang merupakan imitasi buruh dari dunia nyata." (Saleh \& Pitriani, 2018). Keadaan dan situasi tersebut mendorong audien untuk selalu terikat dengan internet dan media sosial, sehingga secara langsung digunakan sebagai cara mendapatkan kebutuhan dan kepuasan, seperti yang dijelaskan dalam asumsi Teori U\&G 2.0. Karena itu, kehadiran social media influencer kemungkinan besar menjadi bagian dari kebutuhan masyarakat modern, sehingga ia menyediakan sebagian informasi penting yang dibutuhkan oleh audien.

Social media influencer menjadi kelompok baru yang bertugas memberikan pemahaman hingga mengubah sikap audien menggunakan internet atau media sosial (Glucksman, 2017),. Mayoritas social media influencer menggunakan platform seperti Instagram, YouTube, Twitter dan Facebook, social media influencer membuat promosi konten brand tertentu dengan tujuan memperoleh 
pengikut dan atau pengakuan sebuah brand di mata konsumennya, termasuk konsep tubuh ideal yang dihasilkan dari hidup sehat. Salah satu social media influencer dengan jumlah pengikut relatif tinggi, ialah Brigita Putra, dengan nama akun @ gita_vbpr. Pengambilan akun tersebut dilatar belakangi bahwa unggahan yang dilakukan oleh Gita sebagai pemilik akun memiliki konsistensi tinggi berkenaan dengan konsep tubuh ideal wanita, gaya hidup, dan kaitannya dengan kesehatan. Selain itu pula, Gita telah memiliki jumlah unggahan berkenaan dengan pembentukan tubuh yang ideal sebanyak 1.196 dengan pengikut sebanyak 302.000. Kenyataan demikian menunjukkan bahwa social media influencer mempenetrasikan sejumlah besar informasi secara efektif kepada semua pengikut secara efektif, sehingga informasi-informasi yang diberikan kemungkinan besar bisa diterima oleh pengguna media sosial secara lebih baik, jika dibandingkan dengan informasi yang diberikan oleh media-media tradisional.

Artikel ini bertujuan memberikan pemahaman kepada masyarakat luas, tentang peran social media influencer mempersuasi serta mempenetrasikan pesanpesan baru kepada masyarakat, khususnya berkaitan dengan konsep tubuh ideal berkaitan dengan gaya hidup, kesehatan. Hal demikian menjadi menarik, karena pandangan masyarakat awam menunjukkan bahwa konsep tubuh ideal dan gaya hidup tidak bisa berdampingan dengan konsep tentang kesehatan. Akun gita_vbpr menunjukkan bahwa ketiga konsep tersebut bisa saling melengkapi. Selain itu, artikel ini bisa memberikan gambaran holistik dan mendalam tentang alasan tingginya jumlah pengikut di akun tersebut. Hal demikian diharapkan bisa mengungkap dan menjelaskan fenomena terkait dengan kepuasan audien ketika menggunakan internet dan media sosial. Karena itu, penulis berharap bahwa artikel ini memberikan kemanfaatan berupa pengetahuan tentang manfaat internet dan media sosial untuk menyebarluaskan informasi kepada masyarakat, sehingga para akademisi, praktisi, dan masyarakat awal bisa memanfaatkan internet dan media sosial untuk menyebarkan informasi-informasi positif. Di samping itu penulis juga berharap artikel ini bisa meningkatkan pengetahuan dan pemahaman kepada akademisi, dan praktisi, tentang peran social media influencer, terkait dengan pendekatan teoritis, Teori U\&G 2.0.

Berdasarkan dari penjabaran di atas, penulis berusaha mendapatkan penjelasan dan gambaran holistik tentang peran social media influencer pada aspek penyampaian informasi kepada audien secara luas. Di samping itu, penulis juga ingin mendapatkan deskripsi dan penjelasan holistik pada aspek pembentukan pesan secara sintaksis dan semantik menggunakan pendekatan analisis isi kualitatif. Dengan demikian, artikel ini diharapkan bisa mendapatkan penjelasan ilmiah tentang peran social media influencer di media sosial, khususnya pada pembentukan makna tentang kesehatan, kepercayaan diri, dan pembentukan tubuh ideal, sebagain bagian dari kehidupan masyarakat modern.

Pengetahuan dan pemahaman tentang social media influencer berkiatan erat dengan sejumlah konsep utama, yang terkait dengan gaya hidup, internet, dan media sosial, karena itu pengetahuan, dan pemahaman tentang konsep-konsep tersebut menjadi penting dipelajari. Konsep paling utama dalam konteks social media influencer, berkaitan dengan media sosial. Media sosial menjadi istilah yang relatif baru namun istilah media sosial saat ini sangat dikenal luas di ranah 
Azizun Kurnia Illahi, Dewanto Putra Fajar, Muhammad Irawan Saputra: Penggunaan Social media influencer Sebagai Usaha Membangun Budaya Masyarakat Digital Tentang Konsep Tubuh Ideal dan Kepercayaan Diri

komunikasi hingga masyarakat awam. Istilah media sosial sejatinya merujuk kepada jaringan interaksional antarpersonal menggunakan internet. Istilah tersebut muncul sebagai kompensasi terhadap munculnya bentuk-bentuk komunikasi model baru, yang memungkinkan pengguna mengakses informasi serta memberikan informasi kepada pengguna lainnya secara real time. Kondisi demikian menjadikan arus informasi yang beredar di masyarakat menjadi sangat cepat dan sangat beragam, sehingga menjadikan informasi menjadi bagian penting dalam kehidupan masyarakat modern saat ini. Kenyataan demikian menjadikan setiap individu di dalam masyrakat modern bisa menjadi komunikator sekaligus komunikan di media sosial, sehingga memunculkan suatu konsep yang dikenal sebagai prosumer informasi-produsen dan konsumen informasi dalam waktu bersamaan. Keragaman informasi yang beredar di media sosial muncul menjadikan masyarakat mendapatkan terpaan informasi yang sangat tinggi, namun seringkali tidak terlalu diperlukan. Di sisi yang lain, media sosial memberikan beragam informasi positif terkait dengan segala sesuatu yang berkaitan dengan perubahan kondisi sosial. Karena itu media sosial berkaitan dengan perubahan kondisi sosial masyarakat.

Kemampuan unggul media sosial memberikan perubahan kepada masyarakat modern berhubungan dengan sifat-sifat media sosial yang berhubungan dengan sifat-sifat media baru (internet). Pada dasarnya, internet merupakan jaringan kerja yang menghubungkan komputer dengan komputer lainnya dalam satu jaringan kerja yang sangat luas. Lebih detail, internet sejatinya merupakan hasil konvergensi teknologis antara teknologi komputerisasi, teknologi informasi, dan teknologi penyimpanan data (Flew, 2007). Konvergensi teknologi tersebut menjadikan internet memiliki sifat interaktif (interactivity) yang tidak dimiliki oleh teknologi komunikasi lainnya. Interaktivitas menjadikan pengguna bisa berkomunikasi secara resiprokal menggunakan teknologi internet, bahkan internet memungkinkan masing-masing individu berkomunikasi secara face-to-face menggunakan jaringan internet. Di samping itu internet memberikan kesempatan luas bagi para pengguna untuk membangun jati diri berbeda dengan jati diri mereka di dunia nyata. Kondisi demikian diidentifikasi oleh (Turkle, 1995) dengan pernyataan bahwa pengguna internet bisa menjadi siapapun dan mendefinisikan ulang jati diri pengguna tersebut (Walther, 2011). Dengan demikian para pengguna internet dilindungi oleh prinsip anonimitas, sehingga mampu memunculkan alterego dari pengguna internet tersebut. Keunggulan internet menyembunyikan identitas penggunanya berpengaruh pada media sosial, karena media sosial notabene menggunakan mekanisme dan teknologi yang sama dengan internet. Hal itu menjadikan media sosial memberikan implikasi besar terhadap kehidupan masyarakat modern, khususnya pengguna media sosial.

Lebih lanjut, social media influencer membutuhkan keahlian untuk dapat mengemas pesan agar dapat mempersuasif dan mengemas beberapa informasi yang dibutuhkan berkenaan dengan konsep tubuh ideal. Terlebih terdapat banyaknya komponen dan juga skala tentang konsep tubuh ideal, sehingga memelukan pengemasan isi pesan dengan baik. Pengemasan pesan pun diharuskan untuk dapat mempersuasif khalayak. (Devito, 2011) mengungkapkan bahwa melakuan persuasi memusatkan perhatian pada upaya untuk mengubah atau memperkuat sikap atau kepercayaan khalayak atau upaya mengajak mereka bertindak dengan cara tertentu. 
Persuasi juga dipahami sebagai usaha mengubah sikap melalui penggunaan pesan dan berfokus pada karakteristik komunikator dan pendengar. Pesan persuasif memiliki beberapa syarat yang harus dipenuhi, sesuai dengan pandangan Crider (Jamiluddin, 2017), yaitu :

a) Pesan haruslah tidak bias. Pada poin ini terdapat tiga hal yang harus dipenuhi supaya pesan yang disampaikan tidak bias, yaitu, Pesan yang disampaikan pada khalayak tidak mengandung atau berisi kebohongan. Penyampaian pesan hendaknya diberi penjelasan seperlunya yang tidak menyimpang dari fakta mengenai produk atau jasa yang dikomunikasikan.

b) Pesan hendaknya berisi dua kepentingan sekaligus, yaitu kepentingan yang ingin disampaikan oleh penyampai dan penerima. Dua kepentingan tersebut hendaknya disampaikan secara seimbang, artinya melalui pesan yang disampaikan benar-benar menunjukkan perbandingan dara yang seimbang, baik sisi positif maupun negatif.

c) Untuk mengemas pesan persuasif tidak menggunakan unsur memaksa, baik paksaan psikologis maupun fisik.

d) Pesan harus memotivasi. Suatu pesan yang dirancang hendaklah dapat mendorong kayak sasaran untuk menentukan pilihan dan keinginannya sendiri.

Artikel ini menggunakan perspektif teori U\&G 2.0 sebagai sarana untuk menganalisis fenomena terkait dengan peran social media influencer di media sosial. Teori U\&G 2.0 diharapkan bisa memberikan pandangan serta penjelasan komprehensif tentang kemunculan dan dampak yang mungkin hadir dari fenomena terkait dengan social media influencer, terutama pada sejumlah aspek penting, yaitu konsep tubuh ideal, gaya hidup, dan kesehatan. Dengan demikian, penulis berharap bahwa bisa memberikan gambaran penting terhadap fenomena terkait dengan penggunaan media dan kepuasan, sebagaimana dijelaskan oleh Teori U\&G 2.0.

\section{Metode Penelitian `}

Penelitian ini menggunakan metode kualitatif dengan teknik analisis isi kualitatif. Teknik analisis isi digunakan untuk mengamati pesan-pesan yang disampaikan oleh social media influencer, terkait dengan sejumlah aspek penting, seperti kesehatan, kepercayaan diri, dan bentuk tubuh ideal. Penggunaan analisis isi kualitatif memungkinkan penulis melihat isi pesan secara lebih dalam, melalui pemahaman makna pesan, termasuk pemahaman aspek sintaksis dan semantik dari pesan-pesan tersebut. Lebih jauh penggunaan analisis isi kualiatif menjadikan penulis bisa memberikan interpretasi secara benar tentang pesan-pesan yang disampaikan, sehingga membantu peneliti untuk menafsirkan pesan-pesan yang ada sebagai suatu cara untuk memahami peran social media influencer ketika memberikan informasi kepada audien.

Artikel ini mengambil social media influencer di akun gita_vbpr sebagai subyek utama dalam penulisan artikel ini. Hal itu menjadikan penulis bisa mengamati dan menjelaskan sebagian dari aktivitas yang dilakukan oleh gita_vbpr, khususnya terkait dengan usahanya menyebarkan pemahaman baru tentang konsep 
Azizun Kurnia Illahi, Dewanto Putra Fajar, Muhammad Irawan Saputra: Penggunaan Social media influencer Sebagai Usaha Membangun Budaya Masyarakat Digital Tentang Konsep Tubuh Ideal dan Kepercayaan Diri

tubuh ideal, gaya hidup, dan kesehatan kepada masyarakat. Karena itu, sebagian unggahan dari akun gita_vbpr, khususnya yang terkait dengan konsep tubuh ideal, gaya hidup, dan kesehatan menjadi obyek dalam artikel ini, karena hal itu merupakan bagian penting yang diamati dalam proses penelitian dan penulisan artikel ini.

Penggunaan analisis isi kualitatif dilakukan oleh penulis untuk membantu peneliti untuk menafasirkan atau menginterpretasikan pesan-pesan yang diberikan oleh social media influencer. Karena itu artikel ini mengamati 55 unggahan, dari sekitar 1.135 unggahan. Namun demikian, pemilihan unggahan dilakukan secara purposif berdasarkan tingkat kepentingan pesan, jumlah retweet pesan, dan hal-hal lain yang membantu penulis menentukan tingkat kepentingan pesan. Hal itu mendorong peneliti untuk menjadikan analisis isi kualitatif tidak hanya sebagai pendekatan metodologis semata, tapi juga memandu peneliti untuk melakukan teknik analisis data, yang dilakukan menggunakan tahapan berikut, sesuai yang dijelaskan oleh (Scheufele, 2008):

a) Penulis mengklasifikasikan dan mengkategorikan semua pesan (unggahan) tekstual di media sosial, terkait dengan topik yang sudah ditentukan oleh penulis, yaitu kesehatan, kepercayaan diri, dan bentuk tubuh ideal.

b) Semua aspek tekstual yang telah dikumpulkan oleh penulis, kemudian akan direfleksikan dan analisis berdasarkan kajian teoritis yang telah dihimpun oleh penulis.

c) Penulis menggunakan teknik logika induktif dan prinsip hermeneutika untuk menginterpretasikan aspek sintaksis dan semantik dari suatu pesan.

d) Penulis menyimpulkan hasil interpretasi dan refleksi dari pesan yang disajikan dalam bentuk paparan deskriptif

Keempat tahapan teknik analisis di atas membantu penulis mendapatkan gambaran holistik dari peran sosial media influencer melalui penggunaan pesan (unggahan) di media sosial. Hal itu menjadikan penulis mampu menjelaskan peran social media influencer ketika mempersuasi audien menggunakan pesan-pesan tertentu, secara lebih baik.

\section{Hasil Penemuan dan Diskusi}

Artikel ini menemukan sejumlah hal penting yang layak dibahas secara lebih dalam, sehingga diperoleh pandangan yang lebih baik tentang peran social media influencer tentang mempersuasi audien menggunakan pesan-pesan persuasif, terkait dengan social branding, tentang kesehatan, kepercayaan diri, dan bentuk tubuh ideal. Secara umum kajian tentang pesan-pesan persuasif difokuskan pada tiga bagian utama, yaitu kajian tentang iklan-iklan komersial, kajian tentang iklaniklan layanan masyarakat, dan iklan-iklan politik (O'Keefe \& Jensen, 2008). Pembahasan dalam artikel ini memfokuskan penggunaan pesan-pesan persuasif yang dilakukan oleh akun gita_vbpr, sebagai cara menarik perhatian audien, selain itu penulis juga tertaik untuk melihat sejumlah tanggapan audien terkait dengan informasi yang diberikan oleh akun gita_vbpr. 


\section{Aspek Retorika sebagai Sarana Mempersuasi Audien}

Selama ini pandangan umum tentang kesehatan, kepercayaan diri, dan bentuk tubuh ideal seringkali dibangun secara terpisah, meskipun ketiganya masih berkaitan satu dan lainnya. Bagi kaum perempuan kesehatan, kepercayaan diri, dan bentuk tubuh ideal menjadi bagian penting yang selalu menyita perhatian, sayangnya ketiganya kemungkinan besar masih sulit dicapai secara bersamaan. Kenyataan demikian mendorong sejumlah social media influencer, termasuk akun @ gita_vbr, atau yang umum disebut sebagai Gita mulai membangun pemahaman bahwa kesehatan, kepercayaan diri, dan bentuk tubuh ideal bisa dibangun secara bersamaan tanpa mengorbankan hal-hal lainnya. Pandangan dan usaha Gita rupanya didukung oleh fakta bahwa ia sampai saat ini memiliki 660.000 subcriber di akun media sosial YouTube dan memiliki sekitar 350.000 pengikut di akun media sosial Instagram. Secara lebih detail Gita rupanya kemungkinan besar berhasil memadukan kemampuan persuasif dan retorika yang baik tentang pentingnya kesehatan, kepercayaan diri, dan konsep tubuh ideal bagi perempuan, serta kemampunnya untuk menghubungkan ketiga konsep terpisah tersebut menjadi satu bagian besar. Alasan-alasan demikian menjadikan Gita memiliki jumlah pengikut yang tinggi, baik di media sosial Twitter dan Instagram.

Artikel ini mengamati seara lebih detail pesan-pesan yang disampaikan oleh Gita, terkait dengan kaitan antara konsep yang disajikan dengan aspek persuasif dan retoris yang muncul dalam sejumlah pesan. Penulis menemukan sejumlah fakta bahwa mayoritas pesan yang diberikan oleh Gita dalam akum media sosialnya menghubungkan aspek-aspek persuasif dan retorika, yang dihimpun dalam bentuk kalimat-kalimat dengan nada positif, yang sejatinya bisa membangun kepercayaan diri bagi audiennya (pengikut). Perhatikan kutipan di bawah ini :

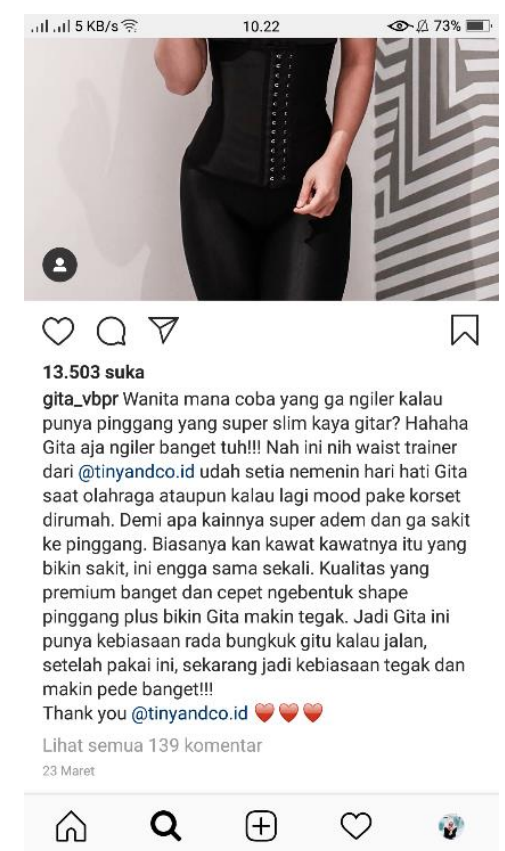

Gambar 1: Pesan (Unggahan) Dalam Akun Gita_Vbpr, Yang Menjelaskan Bentuk Tubuh Ideal Perempuan, Bisa Diperoleh Dari Proses Olahraga, Sekaligus Pakaian (Asesoris) Yang Tepat 
Azizun Kurnia Illahi, Dewanto Putra Fajar, Muhammad Irawan Saputra: Penggunaan Social media influencer Sebagai Usaha Membangun Budaya Masyarakat Digital Tentang Konsep Tubuh Ideal dan Kepercayaan Diri

Gambar di atas menunjukkan foto bentuk tubuh ideal, atau bentuk tubuh proporsional, yang ditampilkan oleh Gita. Menariknya, foto tersebut didukung oleh diskripsi yang menguatkan keterangan dari foto tersebut. Gita menggunakan sejumlah aspek retorika dan persuasif ketika menuliskan keterangan foto tersebut. Kutipan berikut menjelaskan hal tersebut, "Wanita mana coba yang ga ngiler kalau punya pinggal yang super slim kaya gitar?...". Kalimat keterangan tersebut menggunakan sejumlah kata yang mengindikasikan aspek persuasif dan retoris sekaligus, seperti yang muncul pada frase, "Wanita mana coba yang gak ngiler...". Frase tersebut berusaha memancing perhatian audien sekaligus membangun rasa penasaran kepada audien, khususnya audien perempuan. Lebih detail, penggunaan kata "ngiler" memiliki konotasi ketertarikan dan penasaran, karena umumnya kata "ngiler" seringkali bermakna keinginan yang amat tinggi terhadap sesuatu. Pada awalnya kata "ngiler" berasal dari bahasa Jawa, yang bermakna mengeluarkan air liur secara tidak sengaja karena menginginkan sesuatu, khususnya makanan. Namun demikian, saat ini penggunaan kata "ngiler" memiliki perluasan makna, sehingga bisa digunakan untuk menggambarkan ketertarikan yang sangat tinggi terhadap sesuatu. Karena itu, ketika Gita memasukkan kata tersebut dalam keterangan foto, maka ada indikasi bahwa ia berusaha memancing keinginan audien untuk mendapatkan bentuk tubuh seperti yang ditampilkan dalam foto tersebut. Lebih jauh, penggunaan kata-kata serupa bisa ditemukan di mayoritas kata dan kalimat dalam keterangan foto di atas. Selain itu, keterangan foto tersebut menunjukkan bahwa Gita selalu memasukkan aspek persuasif dan retoris dalam keterangan foto tersebut dengan cara menggunakan kata-kata tertentu untuk membujuk audiens.

Kemampuan komunikator, dalam proses persuasi, tidak hanya ditentukan oleh kemampuannya menggunakan kata-kata, tapi juga ditentukan oleh kemampuannya untuk menghubungkan dua konsep berbeda menjadi satu bagian yang saling berkaitan. Gita, di akun gita_vbpr, rupanya mampu memberikan pengetahuan baru bahwa bentuk tubuh ideal, gaya hidup dan kesehatan, bisa dicapai secara bersamaan. Hal demikian ditunjukkan oleh Gita melalui olahraga (latihan fisik), penggunaan asesoris (pakaian yang tepat), dan makanan yang begizi. Hal itu ditunjukkan dalam kutipan di bawah ini : 


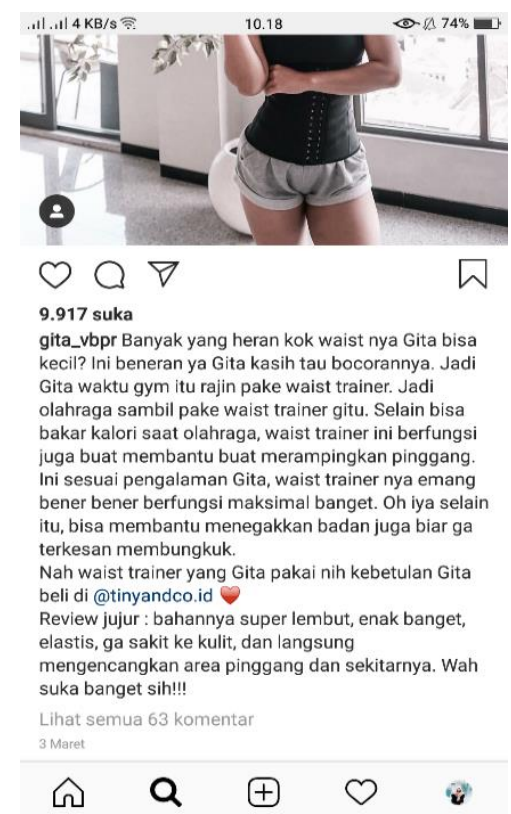

Gambar 2: Pesan (Unggahan) Dalam Akun gita_vbpr Menjelaskan Bentuk Tubuh Ideal Perempuan, Bisa Didapatkan Dari Olahraga Teratur dan Pakaian Yang Tepat

Kutipan di atas menjelaskan bahwa bentuk tubuh ideal diperoleh dengan cara olahraga, dan penggunaan asesoris (pakaian) olahraga yang dikenal sebagai waist trainer. Gita menjelaskan, "Banyak yang heran kok waist nya Gita bisa kecil? Ini beneran ya Gita kasih tu bocorannya. Jadi Gita waktu gym itu rajin pake waist trainer. Jadi olahraga sambil pake waist trainer gitu. ...". Kutipan tersebut setidaknya menunjukkan dua hal penting yang diperlukan untuk mendapatkan tubuh ideal, yaitu latihan fisik atau olahraga teratur, penggunaan asesoris (pakaian) olahraga yang dikenal dengan nama waist trainer. Lebih lanjut penjelasan di atas setidaknyanya menunjukkan tiga hal penting dalam proses persuasi dan proses retorikan yang dilakukan oleh Gita dalam akun gita_vbpr. Pertama, Gita memberikan logika umum untuk membangkitkan rasa penasaran bagi audien, yang terkait secara erat dengan aspek logos (logika umum) dalam proses retorika, yaitu bahwa olahraga, dan asesoris yang tepat bisa membantu membentuk tubuh ideal. (Poster, 2008) menjelaskan bahwa penggunaan logika merupakan bagian penting dalam proses persuasi, karena menunjukkan tingkat ketertarikan audien terhadap suatu obyek tertentu yang ditampilkan. Kedua, semua pesan (unggahan) menampilkan usaha untuk membangun kepercayaan diri audien, terkait dengan bentuk tubuh ideal. Hal itu ditunjukkan dalam kutipan berikut "Jadi olahraga sambil pake waist trainer gitu." Pernyataan tersebut menunjukkan kepada audiens bahwa olahraga menjadi bagian penting bagi individu yang ingin mendapatkan bentuk tubuh ideal, di samping juga menggunakan pakaian olahraga yang tepat pula. Informasi dan pernyatan Gita di media sosial tentang kesehatan, kepercayaan diri, dan bentuk tubuh ideal juga dilakukan dengan cara menunjukkan aktivitas latihan fisik, yang ia la lakukan, sebagai motivasi dan persuasi terhadap audien. 
Azizun Kurnia Illahi, Dewanto Putra Fajar, Muhammad Irawan Saputra: Penggunaan Social media influencer Sebagai Usaha Membangun Budaya Masyarakat Digital Tentang Konsep Tubuh Ideal dan Kepercayaan Diri

\section{Tanggapan Pengikut terhadap Unggahan Informasi}

Informasi-informasi dari akun gita_vbpr, tentang konsep tubuh ideal, gaya hidup, dan kesehatan pada akhirnya diterima oleh sekian banyak pengikut, yang pada hakekatnya bertindak sebagai audien. Hal demikian mendorong audien untuk berkomentar, terkait dengan semua informasi yang telah diterima. Sederhananya, semua komentar dari audien menunjukkan bahwa semua informasi yang diberikan oleh akun gita_vbpr telah mecapai audien secara baik. Namun demikian, tanggapan atau komentar yang diberikan tidak selalu bekaitan dengan informasi yang diterima, karena pada hakekatnya audien memiliki kebebasan penuh ketika memberikan tanggapan, khususnya ketika berada di internet atau media sosial. Kutipan di bawah ini menunjukkan hal demikian.

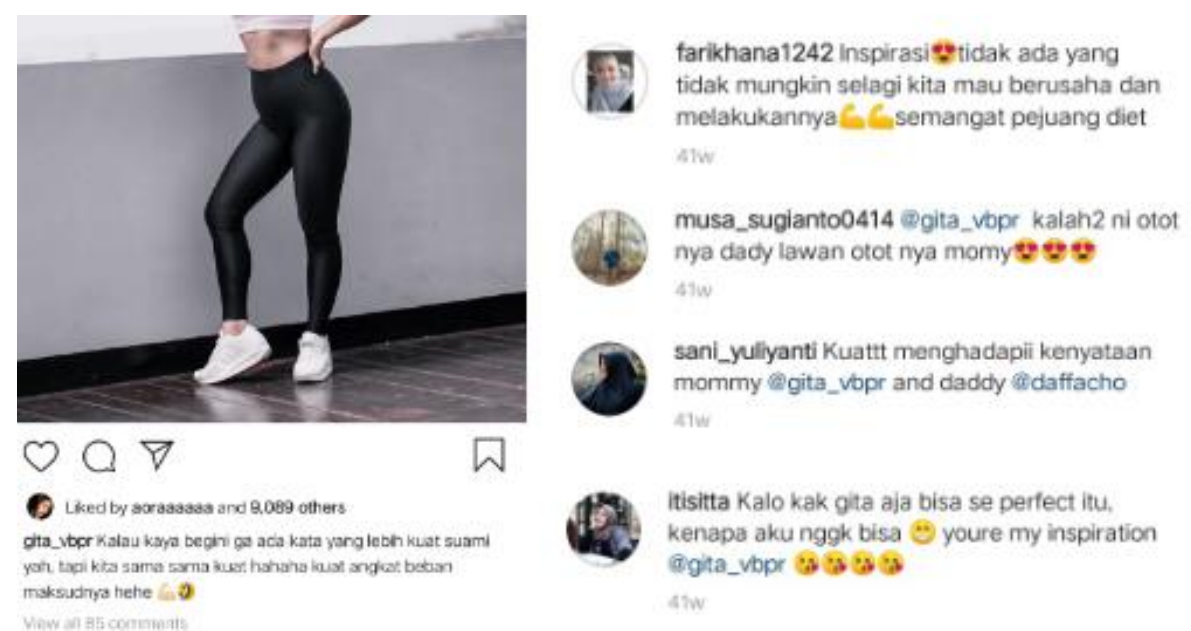

Gambar 3: Komentar Pengikut Di Akun Gita_Vbpr Menunjukkan Perubahan Sikap Postif Dalam Diri Masing-Masing Pengikut Ketika Mendapatkan Sejumlah Unggahan Dari Akun Gita_Vbpr

Mayoritas audien memberikan komentar positif terhadap unggahan akun gita_vbpr di atas. Hal demikian menunjukkan bahwa sebagian besar informasi yang diberikan akun tersebut berhasil dipersepsikan secara mudah oleh audien, sehingga bisa menghasilkan dampak positif, khususnya terhadap kondisi kognitif dan sikap audien. Perhatikan komentar yang diberikan oleh akun farikhana 1242, yang mengatakan "inspirasi...tidak ada yang tidak mungkin selagi kita mau berusaha melakukannya...semangat pejuang diet." Komentar dari akun farikhana 1242 menunjukkan bahwa ia mendapatkan perubahan positif setelah mendapatkan unggahan dari akun gita_vbpr berupa teks motivasi dan foto sekaligus. Perubahan sikap postif dari akun farikhana 1242 ditunjukkan dengan ungkapan, “...tidak ada yang tidak mungkin selagi kita mau berusaha melakukannya...semangat pejuang diet.". Hal demikian secara langsung menujukkan bahwa akun gita_vbpr berhasil menanamkan motivasi postif kepada audiennya, karena akun gita_vbpr tidaha hanya memberikan motivasi berupa ungkapan tulisan, namun juga didukung oleh foto-foto yang mendukung. Karena itu, tampak jelas bahwa akun gita_vbpr berhasil membangun retorika, khususnya pada konsep tubuh ideal, gaya hidup, dan kesehatan. 
Unggahan di atas tidak hanya menanamkan dampak postif dan perubahan sikap pada akun farikhana 1242 semata, tapi juga akun-akun lainnya, seperti yang terjadi pada akun itisitta. Akun itisitta memberikan komentar postif, seperti yang diberikan oleh akun farikhana 1242, yaitu "kalo kak gita aja bisa se perfect itu, kenapa aku gak bisa...youre my inspiration @gita_vbpr..." Komentar demikian menunjukkan bahwa akun itisitta mendapatkan perubahan sikap positif setelah mendapatkan unggahan dan informasi dari akun gita_vbpr. Perubahan-perubahan sikap positif dari masing-masing audien menunjukkan secara langsung bahwa akun gita_vbpr berhasil menanamkan pengaruh dan keyakinan positif, bahwa konsep tubuh ideal, gaya hidup, dan kesehatan bisa didapatkan dengan cara relatif mudah, sekaligus bisa diperoleh secara bersamaan. Hal-hal demikian berhasil menujukkan bahwa audien bisa merasakan perubahan positif dari semua unggahan dan informasi yang diberikan oleh akun gita_vbpr.

Selain unggahan di atas, akun gita_vbpr juga memberikan sejumlah informasi penting kepada audien, yang semuanya juga berdampak pada perubahan sikap audien, khsusunya terkait dengan sejumlah aspek, seperti konsep tubuh ideal, gaya hidup, dan kesehatan. Kutipan di bawah ini menujukkan hal-hal demikian.

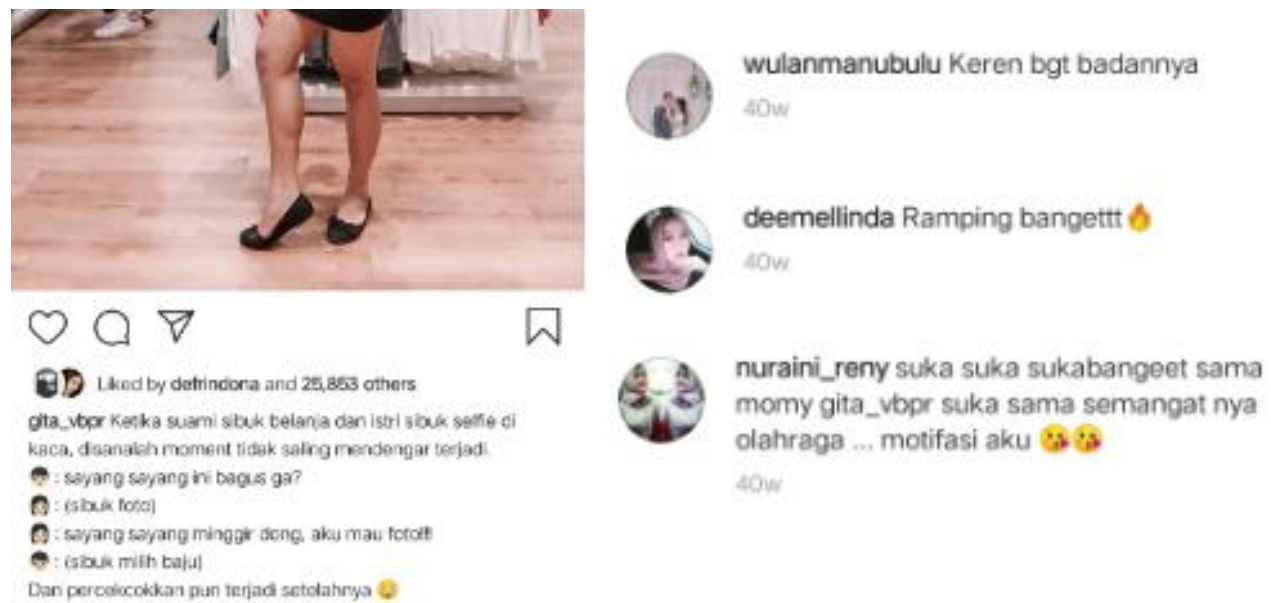

Gambar 4: Komentar di akun gita_vbpr Menunjukkan Perasaan Puas, Setelah Mendapatkan Motivasi Untuk Mencapai Bentuk Tubuh Ideal Dengan Cara Relatif Mudah

Perhatikan komentar yang diberikan oleh akun nuraini_reny "suka sukabanget sama momy gita_vbpr suka sama semangatnya olahraga...motifasi $a k u . . . " K o m e n t a r$ tersebut mengindikasikan bahwa akun nuraini_reny mendapatkan masukkan berharga dari akun gita_vbpr, melalui unggahan informasi di atas, sehingga ada perubahan sikap di dalam diri pemilik akun nuraini_reny. Bukti hadirnya perubahan sikap pada diri pemilik akun nuraini_reny ditunjukkan dengan frase “...suka sama semangatnya olahraga...motifasi aku...", yang secara langsung menujukkan pengakuan bahwa akun gita_vbpr mampu memberikan semangat dan motivasi bagi audien-pemilik akun nuraini_reny-untuk selalu menjaga penampilan tubuh, dengan cara hidup sehat. Dengan kata lain, akun gita_vbpr berhasil menanamkan semangat, motivasi, hingga mengubah sikap audien untuk selalu menjaga penampulan tubuh, dengan cara hidup sehat. Keberhasilan akun 
Azizun Kurnia Illahi, Dewanto Putra Fajar, Muhammad Irawan Saputra: Penggunaan Social media influencer Sebagai Usaha Membangun Budaya Masyarakat Digital Tentang Konsep Tubuh Ideal dan Kepercayaan Diri

gita_vbpr mengubah sikap audien melalui unggahan dan informasi tentang konsep tubuh ideal, gaya hidup, dan kesehatan berkaitan dengan kemampuannya membangun retorika positif sekaligus memberikan rasa puas kepada semua audiennya, dengan sejumlah informasi yang secara umum menjelaskan bahwa konsep tubuh ideal, gaya hidup, dan kesehatan bisa dicapai secara bersamaan dengan cara yang relatif mudah.

\section{Analisis berdasarkan Teori U\&G 2.0}

Fakta-fakta di atas, serta paparan tentang usaha dari akun gita_vbpr menampilkan sejumlah informasi untuk menanamkan pemahaman tentang konsep tubuh ideal, gaya hidup, dan kesehatan, serta tanggapan sejumlah pengikut, yang menunjukkan perubahan sikap, terkait dengan konsep tubuh ideal, gaya hidup dan kesehatan, bisa dijelaskan menggunakan pandangan Teori U\&G 2.0. Teori tersebut menjelaskan bahwa audien bisa mendapatkan kepuasan dari suatu media, jika ia mendapatkan semua yang diharapkan dari media, dalam konteks Teori U\&G 2.0 semua media yang digunakan oleh audien untuk mendapatkan kepuasan ialah internet dan atau media sosial, sebagaimana dijelaskan oleh (West \& Turner, 2019). Karena itu asumsi Teori U\&G 2.0 tidak terlalu banyak berbeda dengan asumsi Teori U\&G konvensional, namun Teori U\&G 2.0 memfokuskan pada media baru dan internet - termasuk juga media sosial. Hal demikian bisa digunakan sebagai sarana untuk menjelaskan fakta-fakta yang muncul di media sosial, termasuk pada informasi atau unggahan yang diberikan oleh akun gita_vbpr dan komentarkomentar pengikut ketika menanggapi unggahan-unggahan yang diberikan oleh akun gita_vbpr.

Semua komentar yang diberikan oleh sejumlah pengikut di akun gita_vbpr sejatinya bisa dibagi menjadi dua kategori besar. Pertama, komentar-komentar positif yang diberikan oleh pengikut, ketika ia mengalami perubahan sikap dan kepuasan ketika melihat dan menerima informasi tentang konsep tubuh ideal, gaya hidup, dan kesehatan. Jenis komentar demikian ditunjukkan oleh akun farikhana 1242 ditunjukkan dengan ungkapan, “...tidak ada yang tidak mungkin selagi kita mau berusaha melakukannya...semangat pejuang diet."; oleh akun itisitta "kalo kak gita aja bisa se perfect itu, kenapa aku gak bisa...youre my inspiration @gita_vbpr..."; dan oleh akun nuraini_reny "suka sukabanget sama momy gita_vbpr suka sama semangatnya olahraga...motifasi aku...”. Semua akun di atas menunjukkan bahwa sebagian besar pengikut mendapatkan kepuasan ketika mendapakan informasi yang diberikan oleh akun gita_vbpr, khususnya informasi terkait dengan konsep tubuh ideal, gaya hidup, dan kesehatan. Hal demikian ditunjukkan dengan sejumlah frase, yang disampaikan oleh audien, seperti "...semangat pejuang diet...", atau "...youre my inspiration...", dan "...motifasi aku...", serta frase-frase lainnya yang belum bisa ditunjukkan oleh penulis. Kedua, komentar-komentar positif dari pengikut, namun tidak berkaitan langsung dengan informasi yang diberikan oleh akun gita_vbpr, namun justru mengomentari penampilan fisik dan kecantikan gita_vbpr. Jenis komentar demikian ditunjukkan oleh akun musa_sugianto0414 "kalah2 ni ototnya dady lawan ototnya momy...", dan oleh akun wulanmanubulu "keren bgt badannya", serta akun-akun lain yang serupa. Komentar-komentar demikian menujukkan bahwa masing-masing audien 
mendapatkan kepuasan sesuai dengan niat awal yang dimilikinya. Sebagian pengikut merasa puas ketika mendapatkan semangat dan perubahan sikap setelah mendapatkan informasi dari akun gita_vbpr, sedangkan pengikut lainnya mendapatkan kepuasan ketika melihat postur tubuh ideal dari akun gita_vbpr. Keadaan dan situasi demikian telah dijelaskan secara gamblang oleh Teori U\&G 2.0 .

\section{Simpulan}

Penelitian ini pada akhirnya bermuara pada suatu kesimpulan penting tentang aspek retorika dan kaitannya dengan aspek media sosial, berupa aspek retorika terkait dengan pembentukan konsepsi tubuh ideal di masyarakat. Karena itu penelitian ini menyimpulkan bahwa komunikator-social media influencermemiliki peran penting dalam membangun pemahaman baru tentang konsepsi tubuh ideal, yang tidak sepenuhnya bertumpu pada pandangan barat, tapi juga bertumpu pada aspek lokal, dan kesehatan tubuh. Kenyataan demikian membangun pemikiran dan pemahaman baru tentang konsep tubuh ideal, tidak hanya berkaitan dengan penampilan fisik dan kecantikan tapi juga berhubungan dengan cara individu menjaga kesehatan tubuh. Hal itu menjadi wahana bagi akun gita_vbpr untuk memberikan motivasi kepada audien — pengikut — untuk bisa tetap semangat mendapatkan tubuh ideal, kesehatan, sebagai bagian dari gaya hidup. Di lain pihak, sejumlah pengikut mendapatkan kepuasan ketika menerima informasi-informasi dari akun gita_vbpr. Sebagian merasakan kepuasan ketika mendapatkan semangat dan perubahan sikap ketika mengonsumsi informasi dari akun gita_vbpr, sementara lainnya mendapatkan kepuasan ketika melihat postur tubuh ideal yang ditampilkan oleh akun gita_vbpr. Semua hal itu, sejatinya berkaitan erat dengan asumsi dasar dari Teori U\&G 2.0.

Penulis memberikan sejumlah rekomendasi dan saran terkait dengan temuan dan hasil dalam artikel jurnal ini. Pertama, penulis menyarankan agar peneliti dan penulis yang memfokuskan kajian pada ranah internet dan media sosial agar bisa melihat dampak positif dan negatif dari penggunaan internet dan media sosial. Kedua, penulis menyarankan dan memberikan rekomendasi tentang pengembangan kajian terkait ranah internet dan media sosial menggunakan perspektif communibiology. Ketiga, meskipun penulis telah berhasil mengidentifikasi fenomena sosial tersebut dan menganalisisnya menggunakan Teori U\&G 2.0, penulis belum bisa memberikan analisis mendalam tentang alasan masing-masing pengikut pada saat memberikan komentar. Karena itu penulis dan peneliti selanjutnya diharapkan bisa membangun refleksi, analisis, dan interpertasi lebih dalam terkait fenomena penggunaan internet dan media sosial, khususnya yang terkait dengan Teori U\&G 2.0. 
Azizun Kurnia Illahi, Dewanto Putra Fajar, Muhammad Irawan Saputra: Penggunaan Social media influencer Sebagai Usaha Membangun Budaya Masyarakat Digital Tentang Konsep Tubuh Ideal dan Kepercayaan Diri

\section{Ucapan Terima Kasih}

Terima kasih penulis ucapkan kepada pihak-pihak yang telah membantu terselesaikannya penelitian ini, diantaranya adalah Gita yang mengizinkan untuk mengambil data, objek penelitian kami, tim peneliti sekaligus tim penulis serta Fakultas Ilmu Sosial dan Ilmu Politik yang telah mendukung tim sehingga terlaksana penelitian dan penulisan artikel ini.

\section{Daftar Pustaka}

Devito, J. A. (2011). Komunikasi Antarmanusia. Komunikasi Antarmanusia. Kuliah Dasar.

Flew, T. (2007). New Media: An Introduction. In Oxford University Press USA.

Gilovich, T., \& Griffin, D. (2012). Introduction - Heuristics and Biases: Then and Now. In Heuristics and Biases. https://doi.org/10.1017/cbo9780511808098.002

Glucksman, M. (2017). The Rise of Social Media Influencer Marketing on Lifestyle Branding: A Case Study of Lucie Fink. Elon Journal of Undergraduate Research in Communications.

Jamiluddin, J. (2017). Problem Pendidikan Anak Tenaga Kerja Wanita Indonesia (TKWI) di Desa Keruak Kecamatan Keruak Kabupaten Lombok Timur. FONDATIA. https://doi.org/10.36088/fondatia.v1i1.84

Morgan, L. H. (2008). Ancient society, or, Researches in the lines of human progress from savagery through barbarism to civilization. In Ancient society, or, Researches in the lines of human progress from savagery through barbarism to civilization. https://doi.org/10.1522/030110918

Morgan, M., Leggett, S., \& Shanahan, J. (1999). Television and Family Values: Was Dan Quayle Right? Mass Communication and Society. https://doi.org/10.1080/15205436.1999.9677861

Nurudin. (2013). Media Sosial Baru dan Munculnya Revolusi Proses Komunikasi. Jurnal Komunikator.

O'Keefe, D. J., \& Jensen, J. D. (2008). Do loss-framed persuasive messages engender greater message processing than do gain-framed messages? A meta-analytic review. Communication Studies. https://doi.org/10.1080/10510970701849388

Poster, C. (2008). Whose Aristotle? Which Aristotelianism? A historical prolegomenon to Thomas Farrell's Norms of Rhetorical Culture. In Philosophy and Rhetoric. https://doi.org/10.1353/par.0.0022

Saleh, G.-, \& Pitriani, R. (2018). Pengaruh Media Sosial Instagram dan WhatsApp Terhadap Pembentukan Budaya "Alone Together." Jurnal Komunikasi. https://doi.org/10.24912/jk.v10i2.2673

Scheufele, B. (2008). Content Analysis, Qualitative. In The International Encyclopedia of Communication. https://doi.org/10.1002/9781405186407.wbiecc134

Turkle, S. (1995). Life on the Screen: Identity in the Age of the Internet. In I Can. https://doi.org/10.1207/s15327965pli0604_5 
Vol. 12, No. 1, Juli 2020, Hal $108-123$

Walther, J. B. (2011). Theories of computer-mediated communication and interpersonal relations. In The SAGE Handbook of Interpersonal Communication.

West, R., \& Turner, L. H. (2019). Introducing Communication Theory. In Making Sense of Messages. https://doi.org/10.4324/9781351130127-13 